\title{
Language Guerrillas: Signing Multilingualism into Action
}

\author{
Angela H. Häusler
}

check for

updates

Citation: Häusler, A.H. Language Guerrillas: Signing Multilingualism into Action. Educ. Sci. 2021, 11, 607. https://doi.org/10.3390/

educsci11100607

Academic Editor: Graham Crookes

Received: 25 April 2021

Accepted: 30 August 2021

Published: 1 October 2021

Publisher's Note: MDPI stays neutral with regard to jurisdictional claims in published maps and institutional affiliations.

Copyright: (C) 2021 by the author. Licensee MDPI, Basel, Switzerland. This article is an open access article distributed under the terms and conditions of the Creative Commons Attribution (CC BY) license (https:// creativecommons.org/licenses/by/ $4.0 /)$.
Center for Language \& Technology, University of Hawai 'i at Mānoa, Honolulu, HI 96822, USA; angelahh@hawaii.edu

\begin{abstract}
This article opens an analytical window into the creation of multilingual guerrilla translations by participants in a preservice language teacher program at a public university in the United States. As an intervention responding to the prevalence of English monolingual signage on this highly diverse university campus, the college students invited a public audience into a joint critical interrogation of implicit institutional language policies, as their signage offered a necessarily incomplete and intentionally makeshift alternative to the official English displays. Inspired by the three-phase model of critical pedagogy, this grassroots endeavor embraced Freire's notion of transformative praxis defined by the symbiotic relation of action and reflection. A closer examination of the scaffolding, which guided the planning and implementation, lends insight into activity design with the potential to nurture an activist aptitude among students. Comments from participants suggest that the conceptual stepping stones towards students' collective critical engagement had a positive influence on their perception of language (teacher) advocacy and activism.
\end{abstract}

Keywords: critical pedagogy; multilingualism; language policies; language activism; linguistic landscape

I will be preparing your arrival as a gardener tends to the garden for the rose that shall come in spring.

-Paulo Freire, Obvious Song

\section{Introduction}

A common trope of higher education today portrays the academy as a global contact zone. This image engages our imagination in the worldwide exchange of ideas and human capital. The fact that linguistic specifications about contact and exchange are rarely necessary to entertain the trope points to a postlingual era, a place where struggles over matters of language are already behind us. The label post, however, is not always interchangeable with past. Quite frequently, it is suggestive of concealed power dynamics.

A few years back, I attended a small exploratory meeting with fellow-language professionals to discuss the state of multilingualism at the University of Hawai'i. Initially, the focus of the discussion was on the ethnic diversity of the student population, reflective of the Islands' demographics and Hawaii's location on the Pacific Rim. In the process of brainstorming, one colleague approached the topic through the angle of language access, a concept enshrined in state law and federal directives. The State of Hawaii's language access law mandates any institution or organization supported by government funds to ensure meaningful language access to public services, for instance via interpreters and translators, although "meaningful" is open for interpretation to account for a wide range of scenarios. The colleague, in our exploratory meeting, raised the question of what the concept of language access has to offer to higher education and to potential students who may not meet the required English proficiency standards for admission put forth by the university. After a moment of uncomfortable silence, the conversation, which had started out in unequivocal support of multilingualism, turned into a defense of the primary role of 
English in American higher education: One participant found English to act as the unifying force of communication in classes and beyond; another suggested English was a quality proof for an awarded degree in the United States. Another fellow wanted us to imagine the dreaded possibility of having to offer lectures through an interpreter or having to translate exams into multiple languages.

A cautious warning was uttered that "we don't want to open Pandora's box and upset the administration with references to language access." In the end, we left the meeting with a rather detailed understanding of what any actions in favor of multilingualism on campus should not, could not, and must not do-in other words, under no circumstances should they pose a threat to the prevalent English monolingual environment at the university. That afternoon, plenty of good intentions to rise to the challenge of a more inclusive and equitable language environment around campus had taken a detour to issue reassurances that hegemonic systems of language serve an allegedly rational, and therefore legitimate purpose. Had we simply crossed our arms in the face of possible change? Had we just made the world, as we know it, a little more permanent?

Such setbacks, as disheartening they may be for educators committed to social change, are not uncommon, as practitioners and proponents of critical pedagogy readily point out. The relinquishing of control [1], the sudden disruption of alienating yet familiar social relations [2] with uncertain alternatives, and commitments to ideological purity [3,4] all factor into our individual and collective repositionings and may quell the oxygen before a critical intervention sees the light of day. Paulo Freire, the late Brazilian educator, philosopher, and, at one point, secretary of education in Brazil's most diverse city, São Paulo, dedicated his life's work to social change. In his writings he argued that collective, transformative action plays a key role in a humanizing approach to education. Progressive relations, whether in or beyond the classroom, ought to nurture encounters with the most fundamental knowledge of all which "is one's certainty that while change is difficult, it is possible" [5] (p. 33).

In recent years, calls from applied linguists committed to social justice have amplified in the face of the ever-tightening grip that neoliberalism holds on education [6-8]. They remind us that, despite various inroads criticality's commitment to diversity, equity, and democracy have made, such advances all too often do not generate the groundswell necessary to a collective transformation of the world around us [9-11]. It has been argued that meso- and macro-level policy changes on language-related issues in education, at minimum, require the support of an active voter base and the leverage of recognized, and perhaps charismatic, experts who can articulate the cause favorably and persuasively to the public [12]. However, the research literature has consistently acknowledged that educators find themselves at the heart of language policy processes, as they exercise a great deal of creative agency in taking up, resisting, and transforming top-down language policies on a daily basis [13-16].

The role students play in policy processes often goes unreported, reinforcing the division between policy agents who create, issue, and implement on the one side and passive policy subjects who merely find themselves at the receiving end. Davis \& Phyak $[17,18]$ have proposed Engaged Language Policy and Practices (ELP) to overcome such divisions in praxis. They enlist critical pedagogy for a participatory ideological analysis of harmful language ideologies and practices and subsequently move members of different communities towards a re-envisioning of egalitarian, multilingual policies from the ground.

Returning to the language classroom, critical pedagogy, in fact, offers educators a scaffolding process to engage with students in transformative praxis, a cycle of action and reflection, which has gained renewed attention among critical applied linguists $[19,20]$. However, even in critical pedagogy literature for language teaching, the action phase remains the most under-researched component of the trifold model [3]. This lacuna is understandable in the face of ever more brazen accountability politics in K-20 education that stifle creative experimentation and make it increasingly difficult to locate "wiggle room" for critical pedagogy [21] in curricula and classroom materials. 
Meanwhile, a major national survey that probed attitudes among U.S. youth toward civic engagement suggests that most young people in the age range between 15 and 24 years hold a negative view of political activism, in particular when it comes to protests [22]. Whether the substantive involvement and leadership of youth in the wave of \#blacklivesmatter protests during the summer of 2020 and in voter drives for the U.S. 2020 presidential election will change such attitudes over time remains to be seen. For language educators dedicated to a critical engagement with social justice, these insights should make it clear that many students, while they are perceptive of society's manifold shortcomings, may find it difficult to locate positions from where, as Freire [5] puts it, a "critical insertion within the world" (p. 36) becomes possible and transformative change achievable. Our classrooms and teacher training programs, as I will further discuss in the context of engaging preservice language teachers in language activism, can be supportive of this personal and professional journey.

In this article, I offer a reflective discussion on strategies devised and insights gained from the implementation of a critical action project with preservice language teachers at the University of Hawai'i at Mānoa. Through a course of action inspired by Freirian critical pedagogy, the group created plurilingual translations of official campus signage which, in guerrilla-style, were added to the original English. The activity was a scaffolding element for a course project in a research study on language advocacy and activism. It aimed to increase the visibility of multilingualism on campus which had been eclipsed by the university's covert language policy. As I will discuss in the following paragraphs, this policy creates a de facto English-dominant environment for a student body that is, in fact, plurilingual.

\section{Diversity in Higher Education}

Never before in the history of American higher education have universities had a more diverse student population. Numerous positive changes around gender, racial, and ethnic diversity are the result of court battles and voter decisions as well as shifting demographics since the 1970s [23]. Between 1996 and 2016 alone, American students of color who were enrolled in undergraduate degree programs increased from roughly 30 to approximately 45 percent [24]. Meanwhile, U.S. college campuses have greatly benefited from the forces of internationalization. The currency of English as a hypercentral language [25] in research and neoliberal globalization continues to attract international students in large numbers. In the same period, their enrollment jumped from 0.9 to 5.3 percent [26]. No single comprehensive data source currently exists that documents students' knowledge of heritage, community, and world languages across U.S. institutions of higher education. However, there are other strong indicators that American university campuses constitute linguistically diverse, intensely multilingual communities: official records document the plurilingualism in U.S. homes [27], the rapid increase of dual-language programs in the P-12 education system [28], incentives such as the Seal of Biliteracy which recognizes proficiency in two or more languages [4], and, last but not least, the enrollment rates of foreign students from countries in which other languages are used in everyday life [29].

U.S. universities have responded to the demographic changes in their student population with strategic planning efforts towards diversity, equity, and inclusion. In fact, prominent accreditation agencies have made diversity policies or variations thereof a requirement for institutional accreditation in the United States. Diversification in this context has been motivated, primarily, by two ideologies that sometimes coexist, at other times collide, or become conflated: the first perspective is grounded in a social-justice oriented liberal multiculturalism (echoing the Civil Rights Act of 1964 and other legal challenges to discrimination); the second perspective co-opts diversity for economic and symbolic gain, also known as "racial capitalism" [30]. In university policies, diversity on either side and across the ideological spectrum is first and foremost, if not exclusively concerned with racial, ethnic, and cultural diversity. By contrast, campuses as multilingual places and linguistic crossroads have received insufficient attention in the language planning of U.S. 
higher education. By and large, American universities embrace a tacit English monolingual approach to the administration of diversity-a praxis followed also in other geographic areas of the Anglosphere [31,32] who observed a similar trend in British and Australian tertiary education systems respectively).

This prompts the question of whether universities, aside from remedial English courses and accredited world language programs, engage in institutional language diversity planning to any significant extent. An apt observation about higher education in the Anglosphere concludes, "In countries such as the United Kingdom, the United States or Australia, where English is not only an academic lingua franca but also the dominant language of public communication, universities have often shown little interest in the linguistic consequences of internationalization" [33] (p. 232).

Track records for the strategic engagement with heritage and community languages, which often differ from the prestigious foreign languages offered at the program level, appear similarly remiss in campuses' meso- and macro-level planning efforts. Ignorance, neglect, or denial of a plurilingual U.S. academy, it could be argued, may limit, or even tarnish a university's diversity brand in domestic and overseas markets as a growing number of institutions worldwide now offer English-medium instruction with the additional benefit of immersion in the local and national languages (cf. $[34,35])$. This is to say that, even when put under the neoliberal microscope-the gaze administrators most likely will adopt today-a greater visibility of the plurilingual potential on campuses is in the best interest of a 21st century institution of higher education.

The pursuit of transformative action towards a linguistically just and equitable university requires us to distinguish between two concepts that sometimes are conflated in everyday discourse: diversity and pluralism, which, in the present context, becomes linguistic diversity on the one hand and plurilingualism on the other. This conceptual distinction is relevant to the implementation of critical pedagogy. Certainly, greater diversity may be a goal in itself, for instance in the admission process of U.S. universities or the hiring of new personnel (keywords diversity rankings, diversity statements, and diversity hires). However, this conceptualization, whether linguistic, cultural, ethnic, economic, gendered, or ideological tends to stop at optics and statistics measured against a white, English monolingual majority culture (cf. [36]), sometimes referred to as the "Anglophone centre" [37]. It falls short on devising a compelling agenda for an ongoing engagement with plural, including plurilingual, relationships sufficiently robust to struggle through the opportunities and problems of social difference.

\section{The Context}

\subsection{Social and Institutional Environment}

A public institution established in 1907 under the Morrill land-grant system, the University of Hawai ' $i$ at Mānoa is subject to federal and state language policies. In the absence of an official language enshrined in the U.S. constitution-which resulted in a potent "masked policy" in favor of English [38] —a majority of U.S. states have adopted statutes and constitutional amendments that designate English as the official language [39,40]. In Hawai 'i, although English and Hawaiian are widely referenced as the State's two official languages, the State Constitution specifies English as the default language for government services. It continues to abate that "Hawaiian shall not be required for public acts and transactions" [41].

This legally established hegemony of English is folded into the Islands' history and its raciolinguistic politics [42,43]. It has resulted in a struggle over decades and centuries, led by Kānaka Maoli whose Indigenous language, 'ōlelo Hawai ${ }^{1} i$, was pushed to the brink of extinction through harmful English-dominant language policies and widespread discriminatory and segregationist practices [44-47]. Hawai' $i$ is one example where the mutual reinforcement between settler colonialism and liberal multiculturalism in the education of a multiethnic population has further strengthend the dominance of English [48-50]. This situation continues to echo through the hallways, linguistic landscapes, and policy docu- 
ments of higher education in the Islands. Relevant university records, such as executive policies and strategic plans, do not make specific reference to a language policy at large for the institution, although, over time, some provisions have been made for the Indigenous language. For instance, the institution accepts theses written in either English or Hawaiian; a few years after the guerrilla initiative took place, the university also began to issue diplomas in the English and Hawaiian languages. Yet, in its absence from most official documents, English becomes materially and ideologically elevated to the commonsensical choice in the pursuit and management of higher education and campus life.

\subsection{Course and Research Design}

The instructional backdrop for the multilingual intervention presented in this article emerged from an upper-level course in the university's applied linguistics program. Compressed into a six-week intensive summer term, the course curriculum set forth an ambitious agenda revolving around teaching languages in linguistically diverse, globally connected societies. Through in-class activities and collaborative projects, students examined some of the overt and covert power dynamics created and sustained through lingual practices. These exercises also aimed at opening ideological spaces for a critical (re)appraisal of multilingualism and its workings in and across different contexts.

The course was offered as an elective, i.e., those enrolled in it engaged, voluntarily, with a social justice perspective as they completed their B.A. program. Most other courses in the program were grounded in mainstream perspectives on second language acquisition and applied linguistics. As a result, the preservice language teachers had little previous exposure to envisioning applied linguistics and world language education through a critical, transformative agenda. The participants, a mix of international students and local residents of Hawai 'i, were plurilingual, although at the beginning of the course, heritage language speakers and those who had learned another language primarily in formal educational settings, displayed a certain hesitancy towards identifying as legitimate speakers of those languages. Among the languages in which students had varying levels of proficiency were Chinese, English, Hawai ‘i Creole (locally known as Pidgin), Japanese, and Korean.

Critical pedagogy, in this scenario, not only furnished a fair share of the course content; it also informed the dialogic approach through which critical consciousness is raised about harmful practices and whereby agency among policy actors is promoted. As mentioned earlier, Davis \& Phyak [17] refer to this conceptual and analytical process as ELP, a methodology that nurtures "growing service to one's own and other institutional communities through modeling service, advocacy and activism" (p. 92).

Each course lesson was built as an iteration of Freire's blueprint problem-posing —critical dialogue-action/reflection. The idea behind this instructional and analytical design was to (re)center all learning, throughout the course, in critical praxis. By incorporating several transformative action activities in the course, which scaffolded the final course assignment, a video-project related to language advocacy, the larger objective was to present teaching for social transformation as an achievable goal to this group of preservice language teachers. In a time that subjects educators to ever more rigorous accountability measures, this messaging appeared particularly important. In the words of Randolph and Johnson [8], "Ideally, a social justice minded teacher would choose a few concrete steps that feel manageable and commit to moving forward one step at a time. No one can do everything, but everyone can do something" (p. 27). Consequently, social justice, in this context, was not enacted as an abstract personal virtue or social ideal. It was envisioned as a situated practice of teaching and research into policy activism, a daily individual and collective struggle in the work of language educators, including plurilingual, preservice language teachers pursuing a degree from universities governed by an English monolingual habitus.

\section{Codefining Key Terminology}

The dialogic unraveling of hidden agendas in the cultural politics of education is a hallmark of critical pedagogy. Critics have challenged critical pedagogy for its grandstand- 
ing concepts such as democracy, voice, empowerment, responsible citizenship, and social justice (cf. [51]). They argue that this disposition, when entering a classroom, may be a factor in accounts of student resistance to critical pedagogy (cf. [52]). To be clear: Freire himself always objected to cognitive and ideological conquests in the name of revolutions and favored dialogical action instead. Meanwhile, he also emphasized that the egalitarian and evolutionary nature of critical dialogue must not be confused with a lack of perspective and direction: "Dialogue does not impose, does not manipulate, does not domesticate, does not 'sloganize.' This does not mean, however, that the theory of dialogical action leads nowhere; nor does it mean that the dialogical human does not have a clear idea of what she wants, or of the objectives to which she is committed" [53] (p. 168).

In the language classroom, democratic dialogue for transformative action can begin with shifting the definitional and cultural authority which resides in grand philosophical concepts such as justice, freedom, equality, and democracy towards a situated, vernacular, cross- or inter-cultural articulation of these constructs. It also can nurture a positive understanding of multilingual citizenship [54]. In a concrete example, the preservice language teachers were asked to approach the term responsibility from different cultural, and later personalized perspectives. Responsibility, in fact, offers a link between critical awareness and translating awareness into action (cf. [55]). Achieving clarity on reciprocity, on mutual interests and obligations is imperative for engaged, collaborative approaches to language policy and planning and, more broadly speaking, for the ethics of language activism (cf. [56]).

The discussion prompt anchored responsibility in the multiethnic environment of Hawai 'i where the Indigenous Hawaiian word kuleana coexists with its English counterpart. Kuleana exceeds Western notions of 'obligation' and 'accountability' in the definition of responsibility, giving further consideration to an individual's or a community's 'right' and privilege' to act upon matters of concern [57]. In this sense, kuleana emphasizes the importance of balance, as obligation can quickly become patronizing if the right and privilege of marginalized groups and individuals to take ownership of their liberation is ignored. Freire, too, highlights that responsible change through critical education embraces the dialectic relationship between authority and freedom, between limits and possibilities [58] (pp. 8,9).

The students were asked to share conceptualizations of responsibility in cultures familiar to them and/or develop their personal definition. Subsequently, they were asked to discuss what their definition(s) of responsibility would mean for building and sustaining pluri-/multi-lingual relationships on campus and in the communities they frequent. Below is a response supplied by one of the students in the course.

"I believe that it's my Kuleana to make our society notice the tendency of thinking one language is better than another. (...) We also could raise awareness for others' kuleana toward multilingual speakers in Hawaii by making them feel proud of their multilingualism and change stereotypes."

By moving from $I$ towards we in the account, the student balances individual and collective responsibilities in the language-based power dynamics of Hawai'i. There is also an emergent sense of the need for alliance building, as the student suggests raising awareness for others' kuleana toward multilingual speakers.

Another student articulated the idea of balance by expressing concern for monolingual speakers amidst the rise of a new powerful paradigm:

"Our kuleana is not only multilingual speakers but also monolingual. Each of them may have different opinions of multilingualism. Some people may not think positive. On the other hand, some people strongly agree with it. I think listening to both opinion (sic) carefully, respecting their opinions is very important."

The resistance to subscribe to a celebratory or totalitarian perspective of multi/plurilingualism as the solution to old and new language problems is a stance that finds support in critical research literature (e.g., [59]). The student's call for careful listening and respect in the discussion serves as a reminder that responsible critical language educators need to 
work towards a mutually committed coexistence between mono- and multi-lingual people (if we accept the abstraction of monolingualism versus multi-/plurilingualism in the first place.). Freire made a similar point about transformative action when he argued that true liberation is not achieved by trading hands between the oppressor and the oppressed. "We cannot say in the process of revolution someone liberates someone else, nor yet that someone liberates himself, but rather that human beings in communion liberate each

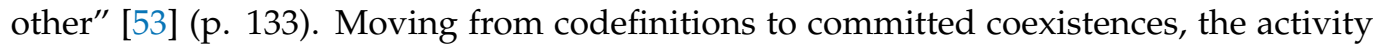
foreshadowed the critical action phase.

\section{Designing a Guerrilla Intervention}

The course syllabus introduced the students to the concept of linguistic landscapes (LLs), a relatively new and flourishing subfield in applied linguistics. It is dedicated to the study of uses, receptions, varieties, and ideologies of language and other semiotic systems on display in public space $[60,61]$. A growing body of research involving students of all ages in the documentation of languages in their local environment, combined with critical reflection on social relations, testifies to LLs' capacity to pair up grassroots participatory research with critical language education (e.g., [62-64]). Findings from educational environments, also known as schoolscapes $[65,66]$ offer an increasingly nuanced understanding of the material (re)presentation of languages and linguistic resources in those settings, in particular the ways that social inequalities among students are perpetuated (e.g., $[67,68]$ ) alongside opportunities for a positive appraisal of multilingual pedagogies and programs [69]. Overall, as research in this area progresses, some authors have highlighted the agentive dynamic of LLs, speaking of linguistic landscaping as a verb (e.g., [70,71]). Yet, partnerships between LL researchers and communities to facilitate a more egalitarian approach to the understanding of linguistic landscapes are still in their infancy.

In critical pedagogy, the teacher's role is to field generative themes in the learning process, i.e., topics that "grow out of student culture" and lend themselves to problemposing critical dialogue [72] (p. 55). Student-run language clubs, religious groups, cafeterias, dorm housing, and other college courses were only a few of the campus reference frames on which students in this class relied heavily when they discussed reading assignments in light of personal experiences. Sometimes, it is important to remind ourselves that, on our teaching quest to transcend classroom walls for the facilitation of real-world experiences and education with a public impact $[73,74]$, we do not have to overcome distance. In this case, campus not only allowed for a critical examination of a lifeworld in which we all were invested; it also opened the possibility for students to engage in critical policy praxis, i.e., in planning together an intervention that attempted to disrupt, if only temporarily, some of the power dynamics solidified in the linguistic landscape of the university.

The prompt for the activity was three-fold: It instructed students, individually or in groups, to take pictures of signs in outdoor spaces that naturalize the status of English as the means of communication at the university. They also were asked to document any visuals in other languages. The pictures were supposed to be compiled into a PowerPoint ${ }^{\circledR}$ presentation to be shared in class the following day. Lastly, the students were directed to index specific signage that would benefit from translation (whether into English or other languages was left open). In this form, the prompt blended three types of subject matter themes: the earlier discussed generative theme; the academic theme supplied by the syllabus, linguistic landscapes; and a topical theme, which Shor [72] defines as "a social question of key importance" to the matter at hand, offered by the teacher. In a more orthodox approach to critical pedagogy, the activity prompt, in particular its reference to the naturalized status of English on campus (a topical theme), could have invited a deeper democratic involvement of the preservice language teachers, allowing them to negotiate some tasks and its overall ideological orientation. Certainly, in an ideal world, all philosophical and pedagogical boxes would be carefully checked, but ideal worlds are not in need of the emancipatory work of critical pedagogy. In the world we know, it is safe to assume that 
educators rarely work under ideal conditions, and critical pedagogy is in dire need in such environments.

When the students returned with their photographic yield to the classroom, they were quick to share their surprise at the status of linguistic diversity in the university's material environment, which points to the subtle, yet prominent role LLs play as a support structure of language myths and dominant language ideologies [67]. Amidst commercially produced official signage, printed and handwritten flyers, a handful of tags and stickers, only two of the roughly eighty signs had been spotted that also displayed Hawaiian and Japanese repertoires. Of course, this was no exhaustive inventory but a reasonable cross section. One student admitted, as they reflected on how they renegotiated the task:

"I stopped taking pictures like half way through the time when I realized everything we found was in English anyways. I never noticed that or ... I didn't really think about campus in that way."

The student was correct. There was no evidence of any form of "contestation" of any aspects of the campus by way of student-made inscriptions, posters, graffiti, or vandalized installations.

Although the project did not strictly adhere to the three-phase model of Freirian critical pedagogy, the photo documentation as an incomplete inventory of campus signage checked boxes on a list of core elements: First, the compilation of campus signage became learning material created by the students themselves [75], allowing the group to discuss places and spaces at the university through the gaze of their peers. Second, the material served as a springboard for critical dialogue, in other words student-generated codifications for problem-posing that would carry the group forward to their guerrilla-style intervention. At this point, the preservice language teachers each selected a sign from their inventory for which they would solicit peer translations. A pooling of the students' plurilingual repertoires was next on the agenda.

This self-assessment of class-internal linguistic resources created opportunities for critical reflections. The discussion was indicative of Kubota's [59] call to overcome a "superficial and abstract celebration of linguistic diversity" (p. 18). For its size, the course, drawing on the students' and the teacher's language backgrounds, was rather resourceful: Japanese, Mandarin, Korean, Hawai'i Creole, and German. Meanwhile, through the process of critical dialogue, the students also noticed that there was a gap between our course-internal language pool and those languages that are strongly present in everyday Island life, for instance, Hawaiian and Filipino. Subsequently, the discussion verged into reflections on the ethnic and socioeconomic stratification of college access, the role of ethnicity and race in choosing a major field of study, and anyone's lack of experience with learning the Indigenous language of the Islands.

\section{Multilingual Translations}

Up to this point, the outlook of the project may suggest a reification of what is now considered a modernist conception of languages as countable entities comprised of fixed structures $[76,77]$. This impression would only hold true if the production process of the plurilingual signage is not taken into account. Translanguaging, a speaker's dynamic deployment of their interdependent linguistic resources $[78,79]$ is a creative communicative strategy that came natural to the plurilingual preservice language teachers-no instruction, no modeling needed. Whether semantic finesses had to be clarified, writing systems compared, or pop culture references traded, translanguaging catalyzed the translations in five different languages onto the cardboard signs. Among the signs translated were "Irrigation Recycled Water/Do not drink," "Ocean-friendly Garden/Conservation Permeability Retention." and "Please Enjoy the Chalk and Chalkboard Tables." Clearly, the students showed a concern for content, lexical, and situational complexity in their selections. At this point, the guerrilla signs were ready to be presented to the campus (Figure 1). For several days, in one instance even for several years, the signs engaged passersby in a collective 
re-envisioning of the university as a linguistically diverse place where people practice plurilingual relationships.



Figure 1. Students posing next to a guerrilla sign displaying.

In subsequent reflections, the group was unanimously positive about the takeaway from this activist experience. One student commented:

"It shows me that nothing is impossible. Those who want to make a difference, whether it's the teacher or the student, can be active. If you want your values and beliefs to be heard, then show everyone what they are and how it may be a benefit."

Another student made a link to the artistic products that involvement with language activism in education may inspire and found the experience could help them on their path forward:

"I learned that it is important to make something creative that many people want to take a look at. Any issues should not be ignored. They should be visible and something everyone thinks and talks about. As a teacher, I would like to assist students in doing that."

About two years later, a strategic multilingual initiative led by faculty from different departments launched a concerted effort to change the English monolingual signage around campus once again. This time, the planning committee focused exclusively on Hawaiian language translations, echoing the university's strategic plan that is committed to making the campus a Hawaiian place of learning. In public presentations, the grassroots multilingual guerrilla action has been referenced by members of the initiative's planning committee as the inspirational predecessor of this now institutionalized enterprise to transform official signage in the linguistic landscape of the campus.

Meanwhile, the students who formed the multilingual guerrilla collective have graduated and stepped into their careers. A longitudinal study on whether and how their involvement with linguistic activism may have shaped their personal and professional trajectories could advance our understandings of the medium- and long-term outcomes when college students, here in their dual role as preservice language teachers, become involved in bottom-up language planning and direct political action. However, equally important in our results-driven academic culture is that we entertain the idea that some of the impact collective transformative action has may not materialize for a long time or may not be easily traceable. 


\section{Leveraging Transformative Action in Language (Teacher) Education}

First things first: there is no singular effective or morally superior way to pursue social justice within the power dynamics that originate or are reinforced by language and language policies. A good strategy to avoid digging ourselves into holes of paradigmatic purity and infinite critical gesturing is to create opportunities for students and future language teachers to experiment with personally meaningful, reflective, hands-on interventions. In the project presented here, which took methodological inspiration from Freirian critical pedagogy, the class came to grapple with friction-filled issues such as elite multilingualism $[80,81]$ and the limits of a politics of representation [82,83]. Ideally, the preservice language teachers would further develop their encounters with these and other topics surrounding social justice, language advocacy, and grassroots policymaking at several stages in their academic program through a diversity of conceptual vocabularies, perspectives, and activist engagement. The multilingual guerrilla translations funneled a disciplinary paradigm shift (the multilingual turn) and a defining concern in critical language studies (the empowerment of marginalized speakers and communities) into a simple, accessible message for a public audience. Translating academic knowledge into the public sphere is a skill, if not a craft, that, while implicitly expected, has not been afforded structured attention in applied linguistics. This skill, however, is necessary to set in motion the forces of transformative change, whether in our schools, in the streets, or at the legislature.

Likewise, students and educators who have been involved in language advocacy and activism will have stories to share about relational solidarity, about failed and successful tactics and strategies to confront and potentially subvert marginalization and erasure perpetuated by language $[84,85]$. Such testimonies, such life experiences, when told forward in our classrooms and communities, have the potential to amplify calls for collective action. The story of the multilingual guerrilla collective traveled across different public spaces and virtual platforms, eventually becoming woven into a new story about change, language policies, and Indigenous futures at the university. Examining these dynamics promises valuable insights into the material processes and impact levels of activist engagement with language policies [86]. Critics may caution that the multilingual ideological lens adopted for this project has its own shortcomings, for instance in the incomplete role the Indigenous language was afforded. Meanwhile, the fact that the language guerrillas paused to reflect on this issue and weighed it with the responsibilities they formulated for themselves and their communities, should not go unnoticed. Limited by the constraints of time and language resources, the intervention could have been dismissed in favor of a more comprehensive representation of community languages and/or by handing off responsibilities to someone else, to another group. Instead, the multilingual guerrilla signage created a material reference for others to pursue change at the university. Rather than aiming for an epistemologically coherent praxis and ideal outcomes, this account reminds us it is the footprints and stepping stones that language activism leaves behind which become part of the windy road that we travel towards social transformation.

\section{Concluding Note}

In his poem Obvious Song, from which I quoted at the beginning of this article, Freire reminds us revolutions have a great deal in common with stewardship for a garden. Sometimes, a trowel is needed to loosen a dense soil before new seeds can be planted. Some seeds may never sprout, while others grow too quick and collapse, as they lack the robust physique of a healthy plant. Gardeners are driven by risk and hope; they work to see the transformation from seed to plant. Importantly, gardeners know there is no harvest without rain.

Funding: This research received no external funding.

Institutional Review Board Statement: The study was conducted according to the principles of the Nuremberg Code, the Belmont Report, the Declaration of Helsinki, and approved by the Institutional Review Board of the University of Hawai' $i$. 
Informed Consent Statement: Informed consent was obtained from all subjects involved in the study.

Data Availability Statement: The data that support the findings of this study are available from the author upon reasonable request.

Conflicts of Interest: The author declares no conflict of interest.

\section{References}

1. Shor, I. When Students Have Power: Negotiating Authority in a Critical Pedagogy; University of Chicago Press: Chicago, IL, USA, 1996.

2. Hooks, B. Teaching to Transgress: Education as the Practice of Freedom; Routledge: London, UK, 1994.

3. Crookes, G.V. Critical ELT in Action: Foundations, Promises, Praxis; Routledge: London, UK, 2013.

4. Giroux, H. Cultural studies, public pedagogy, and the responsibility of intellectuals. Commun. Crit. Cult. Stud. 2004, 1, 59-79. [CrossRef]

5. Freire, P. On the right and duty to change the world. In Pedagogy of Indignation; Macedo, D., Ed.; Routledge: London, UK, 1997; pp. 31-43.

6. Glynn, C.; Weseley, P.; Wassell, B. Words and Actions: Teaching Languages through the Lens of Social Justice; American Council on the Teaching of Foreign Languages: Alexandria, VA, USA, 2014.

7. Piller, I. Linguistic Diversity and Social Justice: An Introduction to Applied Sociolinguistics; Oxford University Press: Oxford, UK, 2016.

8. Randolph, L.J., Jr.; Johnson, S.M. Social justice in the language classroom: A call to action. Dimension 2017, 52, 9-31.

9. Bucholtz, M. White affects and sociolinguistic activism. Lang. Soc. 2018, 47, 350-353. [CrossRef]

10. Kubota, R.; Miller, E.R. Re-examining and re-envisioning criticality in language studies: Theories and praxis. Crit. Inq. Lang. Stud. 2017, 14, 129-157. [CrossRef]

11. Morgan, B.; Mattos, A. Theories and practices in critical language teaching: A dialogic introduction. Rev. Bras. De Linguística Apl. 2018, 18, 213-226. [CrossRef]

12. McGroarty, M. Evolving influences on educational language policies. In Language Policies in Education: Critical Issues; Tollefson, J.W., Ed.; Lawrence Erlbaum: Mahwah, NJ, USA, 2002; pp. 17-36.

13. Johnson, D.C. Language Policy; Palgrave Macmillan: London, UK, 2013.

14. Menken, K.; García, O. Language policy in classrooms and schools. In Language Policy and Political Issues in Education: Encyclopedia of Language and Education; McCarty, T., May, S., Eds.; Springer: Berlin/Heidelberg, Germany, 2016; pp. 211-225.

15. Ramanathan, V.; Morgan, B. TESOL and policy enactments: Perspectives from practice. TESOL Q. 2007, 41, 447-463. [CrossRef]

16. Spolsky, B. Rethinking Language Policy; Edinburgh University Press: Edinburgh, UK, 2021.

17. Davis, K.A.; Phyak, P. Engaged language policy and practices. Lang. Policy 2014, 13, 83-100. [CrossRef]

18. Davis, K.A.; Phyak, P. Engaged Language Policy and Practices; Routledge: London, UK, 2016.

19. Crookes, G.V.; Ziegler, N. Critical language pedagogy and task-based language teaching: Reciprocal relationship and mutual benefit. Educ. Sci. 2021, 11, 254. [CrossRef]

20. Kubota, R. Promoting and problematizing multi/plural approaches in language pedagogy. In Plurilingual Pedagogies: Critical and Creative Endeavors for Equitable Language in Education; Lau, S.M.C., van Viegen, S., Eds.; Springer: Berlin/Heidelberg, Germany, 2020; pp. 303-321.

21. Morgan, B. Fostering conceptual roles for change: Identity and agency in ESEA teacher preparation. Krit. Kult. 2010, 15, 34-55.

22. Jones, R.P.; Cox, D.; Fisch-Friedman, M.; Vandermaas-Peeler, A. Diversity, Division, Discrimination: The State of Young America. Public Religion Research Institute and MTV. 2017. Available online: https:/ / prri.org (accessed on 31 March 2021).

23. Tienda, M. Diversity \# Inclusion: Promoting integration in higher education. Educ. Res. 2013, 42, 467-475. [CrossRef]

24. American Council on Education. College Students Are More Diverse Than Ever. Faculty and Administrators Are Not; Association of American Colleges \& Universities: Washington, DC, USA, 2019; Available online: https:/ /www.aacu.org/ (accessed on 31 March 2021).

25. de Swaan, A. Words of the World: The Global Language System; Polity Press: Cambridge, UK, 2001.

26. Institute of International Education International Student Enrollment Trends, 1948/49-2019/20. Open Doors Report on International Educational Exchange. 2020. Available online: http:/ / www.opendoorsdata.org (accessed on 31 March 2021).

27. U.S. Census Bureau. 2015-2019 American Community Survey (2019: ACS 5-Year Estimates, Table S1601). 2020. Available online: https: / / data.census.gov/cedsci/ (accessed on 31 March 2021).

28. Dual Language Schools. National Dual Language School Directory. 2021. Available online: http://duallanguageschools.org (accessed on 31 March 2021).

29. Israel, E.; Batalova, J. International Students in the United States; Migration Policy Institute: 2021. Available online: https: / / www.migrationpolicy.org/ (accessed on 28 August 2021).

30. Leong, N. Racial capitalism. Harv. Law Rev. 2013, 126, 2151-2226. [CrossRef]

31. Martin, P. 'They have lost their identity but not gained a British one': Non-traditional multilingual students in higher education in the United Kingdom. Lang. Educ. 2010, 24, 9-20. [CrossRef]

32. Yanaprasart, P.; Lüdi, G. Diversity and multilingual challenges in academic settings. Int. J. Biling. Educ. Biling. 2018, 21, 825-840. [CrossRef] 
33. Liddicoat, A.J. Language planning in universities: Teaching, research and administration. Curr. Issues Lang. Plan. 2016, 17, 231-241. [CrossRef]

34. Gallego-Balsà, L.; Cots, J.M. 'Living to the rhythm of the city': Internationalisation of universities and tourism discourse. Lang. Cult. Curric. 2016, 29, 6-21. [CrossRef]

35. Soler, J. University branding and the internationalization of higher education in the Baltic States: The role of language. In Language Perceptions and Practices in Multilingual Universities; Kuteeva, M., Kaufhold, K., Hynninen, N., Eds.; Palgrave Macmillan: London, UK, 2020; pp. 137-163.

36. Piller, I. Monolingual ways of seeing multilingualism. J. Multicult. Discourses 2016, 11, 25-33. [CrossRef]

37. Preece, S.; Marshall, S. Plurilingualism, teaching and learning, and Anglophone higher education: An introduction. Anglophone universities and linguistic diversity. Lang. Cult. Curric. 2020, 33, 117-125. [CrossRef]

38. Schiffman, H. Linguistic Culture and Language Policy; Routledge: London, UK, 1996.

39. Schmidt, R. Language Policy and Identity Politics in the U.S.; Temple University Press: Philadelphia, PA, USA, 2000.

40. Spolsky, B. Does the United States need a language policy, or is English enough? Language policies in the US and beyond. In ACTFL 2005-2015: Realizing Our Vision of Languages for All; Heining-Boynton, A., Ed.; Pearson Education: London, UK, 2006; pp. 15-38.

41. Hawaii Revised Statutes; Legislative Reference Bureau, State Capitol: Honolulu, Hi, USA, 1996; pp. 1-13.

42. Alim, H.S. Introducing raciolinguistics. In Raciolinguistics: How Language Shapes Our Ideas about Race; Rickford, J.R., Alim, H.S., Ball, A.F., Eds.; Oxford University Press: Oxford, UK, 2016; pp. 1-30.

43. Rosa, J.; Flores, N. Unsettling race and language: Toward a raciolinguistic perspective. Lang. Soc. 2017, 46, 621-647. [CrossRef]

44. Wilson, W.H.; Kamanā, K. "For the interest of Hawaiians themselves": Reclaiming the benefits of Hawaiian-medium education. Hūlili 2006, 3, 153-181.

45. Drager, K. Pidgin and Hawai' 'i English: An overview. Int. J. Lang. Transl. Intercult. Commun. 2012, 1, 61-73.

46. Eades, D.; Jacobs, S.; Hargrove, E.; Menacker, T. Pidgin, local identity, and schooling in Hawaii. In Dialects, Englishes, Creoles, and Education, 2nd ed.; Nero, S.J., Ed.; Routledge: London, UK, 2012; pp. 151-175.

47. Higgins, C. Promoting pidgin at the University of Hawaii at Mānoa. In Linguistic Discrimination in U.S. Higher Education; Clements, G., Petray, M.J., Eds.; Taylor \& Francis: Abingdon, UK, 2021; pp. 174-188.

48. Iyengar, M.M. Not mere abstractions: Language policies and language ideologies in U.S. settler colonialism. Decolonization: Indig. Educ. Soc. 2014, 3, 33-59.

49. Halagao, P. Equity in learning: Meeting the needs of multilingual students in Hawaii. Kappa Delta Pi Rec. 2017, 53, 91-94. [CrossRef]

50. Dorner, L.M.; Cervantes-Soon, C.G.; Heiman, D.; Palmer, D. “Now it's all upper-class parents who are checking out schools": Gentrification as coloniality in the enactment of two-way bilingual education policies. Lang. Policy 2021, 20, 1-27. [CrossRef]

51. Pennycook, A. Critical Applied Linguistics: An Introduction; Routledge: London, UK, 2001.

52. Thomson-Bunn, H. Are they empowered yet? Opening up Definitions of Critical Pedagogy. Composition Forum 2014, 29. Available online: http: / / compositionforum.com/ (accessed on 31 March 2021).

53. Freire, P. Pedagogy of the Oppressed; Ramos, M.B., Translator; Continuum: Boston, MA, USA, 1970.

54. Phyak, P.; Rawal, H.; De Costa, P.I. Dialogue as a decolonial effort: Nepali youth transforming monolingual ideologies and reclaiming multilingual citizenship. In A Sociolinguistics of the South; Heugh, K., Stroud, C., Taylor-Leech, K., de Costa, P.I., Eds.; Routledge: London, UK, 2021; pp. 155-170.

55. Silverman, S.K. What is diversity? An inquiry into preservice teacher beliefs. Am. Educ. Res. J. 2010, 47, 292-329. [CrossRef]

56. Low, S.M.; Merry, S.E. Engaged anthropology: Diversity and dilemmas. An introduction to supplement 2. Current Anthropology 2010, 51, S203-S226. [CrossRef]

57. Pukui, M.K.; Elbert, S.H. Hawaiian Dictionary; University of Hawaii Press: Honolulu, HI, USA, 1986.

58. Freire, P. On the spirit of this book. In Pedagogy of Indignation; Macedo, D., Ed.; Routledge: London, UK, $1997 ;$ pp. 3-29.

59. Kubota, R. The multi/plural turn, postcolonial theory, and neoliberal multiculturalism: Complicities and implications for applied linguistics. Appl. Linguist. 2014, 37, 474-494. [CrossRef]

60. Landry, R.; Bourhis, R.Y. Linguistic landscape and ethnolinguistic vitality: An empirical study. J. Lang. Soc. Psychol. 1997, 16, 23-49. [CrossRef]

61. Shohamy, E.; Gorter, D. Introduction. In Linguistic Landscape: Expanding the Scenery; Shohamy, E., Gorter, D., Eds.; Routledge: London, UK, 2009; pp. 1-10.

62. Sayer, P. Using the linguistic landscape as a pedagogical resource. ELT J. 2010, 64, 143-154. [CrossRef]

63. Burwell, C.; Lenters, K. Words on the street: Investigating linguistic landscapes with urban Canadian youth. Pedagog. Int. J. 2015, 10, 201-221. [CrossRef]

64. Li, J.; Marshall, S. Engaging with linguistic landscaping in Vancouver's Chinatown: A pedagogical tool for teaching and learning about multilingualism. Int. J. Biling. Educ. Biling. 2020, 23, 925-941. [CrossRef]

65. Brown, K.D. Estonian schoolscapes and the marginalization of regional identity in education. Eur. Educ. 2005, 37, 78-89. [CrossRef] 
66. Brown, K.D. The linguistic landscape of educational spaces: Language revitalization and schools in southeastern Estonia. In Minority Languages in the Linguistic Landscape; Gorter, D., Marten, H.F., van Mensel, L., Eds.; Palgrave Macmillan: London, UK, 2012; pp. 281-298.

67. Przymus, S.D.; Kohler, A.T. SIGNS: Uncovering the mechanisms by which messages in the linguistic landscape influence language/race ideologies and educational opportunities. Linguist. Educ. 2018, 44, 58-68. [CrossRef]

68. Suuriniemi, S.-A.; Satokangas, H. Linguistic landscape of Finnish school textbooks. Int. J. Multiling. 2021, 1-19. [CrossRef]

69. Menken, K.; Rosario, V.; Valerio, L.A.G. Increasing multilingualism in schoolscapes: New scenery and language education policies. Linguist. Landsc. 2018, 4, 101-127. [CrossRef]

70. Coulmas, F. Linguistic landscaping and the seed of the public sphere. In Linguistic Landscape: Expanding the Scenery; Shohamy, E., Gorter, D., Eds.; Routledge: London, UK, 2008; pp. 13-24.

71. Hult, F. Drive-thru linguistic landscaping: Constructing a linguistically dominant place in a bilingual space. Int. J. Biling. 2014, 18, 507-523. [CrossRef]

72. Shor, I. Empowering Education: Critical Teaching for Social Change; University of Chicago Press: Chicago, IL, USA, 1992.

73. Narcy-Combes, M.-F.; Narcy-Combes, J.-P.; McAllister, J.; Leclère, M.; Miras, G. Language Learning and Teaching in a Multilingual World; Multilingual Matters: Bristol, UK, 2019.

74. Myers, C.B.; Myers, S.M.; Peters, M. The longitudinal connections between undergraduate high impact curriculum practices and civic engagement in adulthood. Res. High. Educ. 2019, 60, 83-110. [CrossRef]

75. Crookes, G. Critical pedagogy in language teaching. In The Encyclopedia of Applied Linguistics; Ortega, L., Ed.; Wiley Blackwell: Hoboken, NJ, USA, 2012; pp. 1-9.

76. Makoni, S.; Pennycook, A. Disinventing and Reconstituting Languages; Multilingual Matters: Bristol, UK, 2007.

77. García, O.; Kleyn, T. Translanguaging theory in education. In Translanguaging with Multilingual Students: Learning from Classroom Moments; García, O., Kleyn, T., Eds.; Routledge: London, UK, 2016; pp. 9-33.

78. García, O.; Wei, L. Translanguaging: Language, Bilingualism and Education; Palgrave Macmillan: London, UK, 2014.

79. Wells, N. Translanguaging and collaborative creative practice: Communication and performance in an intercultural theatre group. In Translanguaging as Everyday Practice; Mazzaferro, G., Ed.; Springer: Berlin/Heidelberg, Germany, 2018; pp. $195-213$.

80. De Costa, P. Elite multilingualism, affect and neoliberalism. J. Multiling. Multicult. Dev. 2019, 40, 453-460. [CrossRef]

81. Ortega, L. SLA and the study of equitable multilingualism. Mod. Lang. J. 2019, 103, 23-38. [CrossRef]

82. Pickering, M. Stereotyping: The Politics of Representation; Palgrave: London, UK, 2001.

83. Phipps, A. Decolonising Multilingualism: Struggles to Decreate; Multilingual Matters: Bristol, UK, 2019.

84. Häusler, A.H.; Leal, P.; Parba, J.; West, G.B.; Crookes, G.V. "How did you become political? ": Narratives of junior researchpractitioners in applied linguistics. Crit. Inq. Lang. Stud. 2018, 15, 282-301.

85. Halagao, P.E.; Lupenui, C.K. Hawai 'i breathes multilingualism. In The Value of Hawaii 3: Hulihia, the Turning; Goodyear-Ka'ōpua, N., Howes, C., Osorio, J.K., Yamashiro, A., Eds.; University of Hawaii Press: Honolulu, HI, USA, 2020; pp. $186-193$.

86. Flores, N.; Chaparro, S. What counts as language education policy? Developing a materialist anti-racist approach to language activism. Lang. Policy 2018, 17, 365-384. 